IZA DP No. 5464

Works Councils, Wages, and Job Satisfaction

Christian Grund

Andreas Schmitt

January 2011 


\title{
Works Councils, Wages, and Job Satisfaction
}

\author{
Christian Grund \\ University of Würzburg \\ and IZA
}

Andreas Schmitt

University of Würzburg

\section{Discussion Paper No. 5464 \\ January 2011}

IZA

P.O. Box 7240

53072 Bonn

Germany

Phone: +49-228-3894-0

Fax: +49-228-3894-180

E-mail: iza@iza.org

Any opinions expressed here are those of the author(s) and not those of IZA. Research published in this series may include views on policy, but the institute itself takes no institutional policy positions.

The Institute for the Study of Labor (IZA) in Bonn is a local and virtual international research center and a place of communication between science, politics and business. IZA is an independent nonprofit organization supported by Deutsche Post Foundation. The center is associated with the University of Bonn and offers a stimulating research environment through its international network, workshops and conferences, data service, project support, research visits and doctoral program. IZA engages in (i) original and internationally competitive research in all fields of labor economics, (ii) development of policy concepts, and (iii) dissemination of research results and concepts to the interested public.

IZA Discussion Papers often represent preliminary work and are circulated to encourage discussion. Citation of such a paper should account for its provisional character. A revised version may be available directly from the author. 
IZA Discussion Paper No. 5464

January 2011

\section{ABSTRACT \\ Works Councils, Wages, and Job Satisfaction}

We investigate the effects of works councils on employees' wages and job satisfaction in general and for subgroups with respect to sex and occupational status. Making use of a German representative sample of employees, we find that employees, who move to a firm with a works council, report increases in job satisfaction, but do not receive particular wage increases. Especially the job satisfaction of female employees is affected by a change in works council status. However, we do not find support for the hypothesis that the introduction of a works council itself increases wages or job satisfaction for the employees staying at the firm.

JEL Classification: M5, J30, J53

Keywords: job satisfaction, wages, works councils

Corresponding author:

Christian Grund

Department of Business and Economics

University of Würzburg

Sanderring 2

97070 Würzburg

Germany

E-mail: ch.grund@uni-wuerzburg.de 


\section{Introduction}

Works councils - representing the workforce of a firm - are supposed to function as firm-level complements to national or sectoral labor negotiations in several countries. They are supposed to foster communication between employees and management and to build trustful and cooperative relations within the firm. The intended purpose is therefore to create some kind of economic rent rather than purely counteract the decision of the management in order to redistribute rents in favor of employees. Theoretical considerations and empirical evidence show that the presence of works councils may affect both the allocation and the distribution of rents (Freeman and Lazear, 1995; Addison et al., 2001). The possible efficiency effect, for instance driven by a voice function in the sense of Hirschman (1970), is also beneficial for the employer.

Works councils do not have the right to bargain over wages in general. They may only negotiate issues with the local management that are not covered by collective agreements with unions. However, works councils may influence wages indirectly even without being directly involved in the bargaining process. Works councils may use their codetermination rights on many other issues for rent-seeking activities and informal negotiations with the management. If they fail to reach an agreement in informal negotiations with the management, works councils can hinder or delay decisions on issues with codetermination rights. Works councils' opportunities for a wage premium include allocating workers into higher defined occupational wage groups or working towards wages above the collective wage agreements.

Works councils may also influence employees' job satisfaction both directly and indirectly. They usually have codetermination rights on working time regulations as well as health and safety issues at the workplace. Besides they may affect changes in work processes, the working environment and job content. Moreover, they may use their bargaining power to negotiate work practices that require lower effort costs of the employees (Hübler and Jirjahn, 2003). If they use these rights in favor of the employees, an increased level of job satisfaction may occur. 
The aim of this study is to examine the impact of works councils on wages and job satisfaction. In contrast to some previous studies, which have mostly used establishment data, we focus on the employees' perspective. We use data from the German Socio-Economic Panel (GSOEP) of the years 2001 and 2006. The GSOEP is a rich representative data set of people living in Germany. We examine changes in the works council's status on wages and job satisfaction. We argue that certain groups of employees may benefit more than others and therefore, we also analyse whether subgroups of employees with respect to sex (men vs. women) and occupational status (blue collar vs. white collar workers) are affected in particular. Moreover, the overall sample contains stayer and those employees, who move to another firm during the observation period. A works council is introduced in certain firms when considering stayer. Mover are likely to switch to firms with existing works councils. This is the first contribution on the topic with an explicit distinction between stayer and mover.

Previous studies on the effects of works councils and wages use establishment data by the majority. Most focus on consequences from a firm's perspective, e.g. on productivity and profits (Addison et al., 1996, 2000, 2001; Zwick, 2004) or investments (Askildsen et al., 2006; Addison et al., 2007). Some others examine the interactive role of collective agreements and works councils on the wage policy of firms (Heywood et al., 1998; Heywood and Jirjahn, 2002; Nergaard et al. 2009) or the wage level (Hübler and Jirjahn, 2003). Addison et al. (2010) use German linked employer-employee data (LIAB) for their cross section analysis of the year 2001. They find a positive relation between wages and works councils in general and in particular for women. This result has also been found by Gartner and Stefan (2004) as well as Heinze and Wolf (2010). To the best of our knowledge there is just one study that also uses individual data over time. Based on the GSOEP and the IAB data, Kraft and Lang (2008) focus on the introduction of a works council and do not find an effect on wages. They neither distinguish between job mover and stayer nor control for the economic situation of the firms.

Freeman (1978) was one of the first, who argues that job satisfaction is an economically relevant variable. Several contributions examined the effect of unions on job satisfaction since then (e.g. Borjas, 1979; Bender and Sloane, 1998; Hammer and Avgar, 2005; Artz, 2010). These studies focus on the U.S., where unions usually 
act at the firm level as works councils do in other countries. However, still only little attention has been paid to the influence of works councils on job satisfaction. One exception is the study by Jirjahn and Tsertsvadze (2006). They use the GSOEP data of 2001 and find that job satisfaction is negatively associated with the existence of works councils on average. They also show some differences with regard to occupational status, but were not able to examine the development over time due to lack of longitudinal data.

In this contribution we built on the existing literature and proceed in some respects. We have information on the existence of a works council in an employee's firm for some points of time and are not limited to a cross section study. We focus on both wages and job satisfaction. We also control for the economic situation of firms and separate stayer from job mover. This latter important differentiation is used since results may be driven by employees, who change their firm during the observation period.

This contribution will proceed as follows: Based on some theoretical considerations, we derive hypotheses for the effects of works councils on employees' wages and job satisfaction in general and for certain subgroups in section II. We then describe the data and variables (section III) before presenting and discussing the results in section IV and V. Section VI concludes.

\section{Theoretical considerations and hypotheses}

We have already stated above that works councils act as a body of control of collective agreements on the firm level. Formally they have no impact on wage bargaining with the management. Moreover, works councils may have an indirect influence on wages by making use of their codetermination rights. These rights include the introduction of new payment methods or new technologies designed to monitor employees' performance, the regulation of working time as well as health and safety issues. If works councils and the management fail to reach an agreement, works councils can threaten to be uncooperative at issues with considerable codetermination rights. Two possibilities may be relevant: First, they can participate in wage agreements above the collectively bargained levels. Second, they can 
negotiate about the allocation of employees in higher wage groups. Therefore, we formulate:

Hypothesis 1: Wages are increased by works councils.

Works councils may also affect employees' job satisfaction. On the one hand, some arguments hint for a negative relation. Freeman and Rogers (1999) point out that employees prefer the possibility of direct participation and autonomy at the workplace. The existence of a works council may lead to a stronger formalization of intra-firm decision-making processes and thus the possibilities of employees' direct participation are limited. Moreover, works councils may aim to mobilize employees to reach a stronger support in negotiations with the employer and a better chance to enforce their demands. Therefore, works councils may create dissatisfaction among employees by revealing certain problems.

On the other hand, severe arguments speak for a positive interrelation of works councils and job satisfaction. Analogously to unions (see Freeman and Medoff, 1984) works councils act as a collective voice institution in the sense of Hirschman (1970). This enables employees to express their dissatisfaction with certain working conditions instead of quitting their jobs. The employer is interested in such decentral information and thus in adjusting the working conditions with respect to employees' preferences. This may lead to a lower turnover rate and higher motivation. Without a works council the problem occurs that contributions to improvement of working conditions have the character of public goods. Employees will act as free-riders instead of engaging in an improvement. Therefore, a works council aggregates employees' preferences and communicates them to the employer. If the employer listens to works councils' advices and improves working conditions accordingly, employees’ job satisfaction will increase.

Additionally, a works council can increase trust between the employer and the workforce (Freeman and Lazear, 1995; Addison et al., 2001; Frege, 2002; Jirjahn and Kraft, 2007; Jirjahn, 2010). Without a works council employees have only vague information about the economic situation of the firm. Usually, employees are willing to make concessions in the case of severe economic problems of the firm. Hence, 
there is an incentive for the firm to feign a crisis. Anticipating this opportunistic behaviour, employees may then abstain from concessions in any case. A works council with information rights concerning the firm's economic situation can then foster trust between the employer and employees and, thus, increase empoyees' job satisfaction.

Similar, such trust considerations may also reduce ratchet effect problems (Laffont and Tirole, 1988; Hübler and Jirjahn, 2003; Jirjahn, 2010). Employees receive payments for their performance. If they fear that the employer will alter future payments with respect to their past performance, they will withhold efforts. A works council provided with codetermination rights in this issue can hinder an unjustified increase in target levels and again protect employees' interests. This may lead to an increase in their job satisfaction.

Finally, fairness considerations may also be relevant. Not only the result of decisions, but also the decision-making process is important for employees. Respect and appreciation by the employer influence employees' job satisfaction positively (Frey et al., 2004; Jirjahn and Tsertsvadze, 2006). A works council may therefore lead to an increase of procedural fairness from employees' view and a rise of their job satisfaction.

We think that these positive effects of works councils outweigh the possible negative aspects and formulate

Hypothesis 2: Employees' job satisfaction is increased by works councils.

If works councils indeed increase wages and job satisfaction of employees, the question follows directly, whether certain groups of employees benefit more than others. The gender pay gap is a well known empirical fact. Several possible explanations such as job segregation, gaps in employment history, turnover, training and discrimination have been examined (e.g. Light and Ureta, 1990; Phipps et al., 2001; Bayard et al., 2003; Gardeazabal and Ugidos, 2005; Flabbi, 2010). Then it is quite straightforward to argue that the presence of an institution as a works council makes direct wage discrimination for an employer much more difficult. Detecting an uneven pay, the works council may again threaten to cancel cooperation. Jirjahn and 
Kraft (2007) state that works councils aim to reduce the wage dispersion, since it reflects the heterogeneity of the employees. However, works councilors may also consider the interests of male employees since employment rates of women are lower and male employees accumulate the majority in many firms. We will empirically examine particular effects by looking at subgroups of female and male employees.

There may also be differences between blue collar and white collar employees. Some codetermination rights such as rights concerning working time regulations for shift working are relevant for blue collar workers in particular. Besides, direct communication with the management and participation is less possible for blue collar workers. An existing works council can engage for this subgroup of employees and represent their interests to the management, which may lead to particular effects on job satisfaction.

\section{Data, Variables and Statistical Procedure}

\section{Data}

Our empirical investigation is based on the German Socio-Economic Panel (GSOEP), which is a yearly representative panel survey of individuals living in Germany (see http://www.diw.de/en/soep for a detailed description of the data set). The GSOEP encompasses numerous topics which include demographic characteristics as well as characteristics of employees' firms and jobs including wages and job satisfaction. Information on the existence of a works council in an employee's plant is only collected in the years 2001 and 2006. We consider employees of private sector firms with five or more employees. We exclude civil servants from our analysis and restrict our sample to full- and part-time employees between 18 and 65 of age. About half of them work in a firm, which is covered by a works council.

We want to focus on changes in works council status and distinguish between two groups of employees with respect to works council status in particular: The first group includes individuals, who neither work in a firm with a works council in 2001 nor in 2006. The second do not report a works council in 2001, but do so in 2006 . Due to these restrictions we get a balanced panel with 2042 observations and 1021 
employees. There are changes in works council status due to two different phenomena. First, employees stay at their firm and a works council is introduced. Second, the employee moves to another firm during the observation period. We distinguish between mover and stayer in our empirical analysis.

\section{Variables}

The gross monthly wage is our first dependent variable. As already suggested by Mincer (1974) and applied in countless studies on wage determination before, we use logs of wages. The wages of the year 2001 are adjusted to prices of the year 2006 by the consumer price index to make the data comparable. Table 1 shows the descriptive statistics. From 2001 to 2006 the average wage level increases from $2240 €$ to $2350 €$. Employees' job satisfaction is our second dependent variable. Respondents have to answer the question "How satisfied are you with your job?", which is coded on an 11-digit scale from 0 (totally unhappy) to 10 (totally happy). The average level of job satisfaction decreases from 7.19 in 2001 to 6.71 in 2006.

The existence of a works council is used as a dummy variable (1=yes, $0=$ no). Almost 20 percent of employees without a works council in 2001 report a works council five years later. Some other variables are also included in the estimations. In order to determine the effect of works councils on wages, we control for several individual and job based characteristics including age, years of schooling and dummies for region, marital status, sex, nationality as well as actual working hours (per week), tenure (in years) and dummies for job status (blue collar vs. white collar workers), type of working contract (part-time vs. full-time), industry and firm size. We also control for the economic situation of a firm in terms of employees concerns about job security. Next to health status the gross monthly wage is used as an additional independent variable in the job satisfaction model. 


\begin{tabular}{|c|c|c|c|c|}
\hline & Mean & SD & Mean & SD \\
\hline Gross monthly wage & 2238.89 & 1220.02 & 2350.53 & 1358.77 \\
\hline Job satisfaction & 7.19 & 1.97 & 6.71 & 1.93 \\
\hline Works council (dummy, 1=yes) & 0 & & 0.189 & \\
\hline \multicolumn{5}{|l|}{ Individual Characteristics } \\
\hline Age (in years) & 38.34 & 8.79 & 43.34 & 8.77 \\
\hline Female (dummy, 1=yes) & 0.421 & & 0.421 & \\
\hline German (dummy,1=yes) & 0.945 & & 0.950 & \\
\hline Marital status (dummy, 1=married) & 0.663 & & 0.714 & \\
\hline Residence in East-Germany (dummy, 1=yes) & 0.308 & & 0.297 & \\
\hline Years of schooling & 12.04 & 2.30 & 12.07 & 2.29 \\
\hline \multicolumn{5}{|l|}{ Health status: } \\
\hline Very good & 0.131 & & 0.069 & \\
\hline Good & 0.507 & & 0.484 & \\
\hline Satisfactory & 0.295 & & 0.352 & \\
\hline Poor & 0.061 & & 0.087 & \\
\hline Bad & 0.006 & & 0.009 & \\
\hline \multicolumn{5}{|l|}{ Job Characteristics } \\
\hline Actual work time per week & 41.48 & 11.31 & 41.16 & 10.74 \\
\hline Blue collar worker (dummy, 1=yes) & 0.410 & & 0.398 & \\
\hline Fulltime (dummy, 1=yes) & 0.823 & & 0.812 & \\
\hline Tenure (in years) & 6.84 & 6.84 & 9.97 & 7.69 \\
\hline \multicolumn{5}{|l|}{ Industry: } \\
\hline Construction & 0.126 & & 0.111 & \\
\hline Financal/Corporate Services & 0.149 & & 0.141 & \\
\hline Manufacturing & 0.311 & & 0.312 & \\
\hline Public/Private Services & 0.097 & & 0.114 & \\
\hline Retail/Tourism/Transportation & 0.317 & & 0.322 & \\
\hline \multicolumn{5}{|l|}{ Firm size: } \\
\hline 5 to 19 employees & 0.422 & & 0.364 & \\
\hline 20 to 199 employees & 0.447 & & 0.426 & \\
\hline 200 to 1999 employees & 0.083 & & 0.121 & \\
\hline 2000+ employees & 0.048 & & 0.089 & \\
\hline \multicolumn{5}{|l|}{ Concerns about job security: } \\
\hline Not concerned at all & 0.451 & & 0.314 & \\
\hline Somewhat concerned & 0.417 & & 0.487 & \\
\hline Very concerned & 0.132 & & 0.199 & \\
\hline Observations & 1021 & & 1021 & \\
\hline
\end{tabular}




\section{Statistical Procedure}

In the empirical section of this contribution we start with some descriptive statistics by comparing wages (job satisfaction) between the two groups "works council in 2006" and "no works council in both years". We already examine subgroups of mover and stayer here. Furthermore, we apply a difference-in-differences approach in order to examine the effect of a works council's introduction on wages and job satisfaction respectively. Using such an approach, we take the issue of causation into account since we examine changes for individuals over the years. As mentioned above, most previous studies just examined cross section data. Next to general estimations we run estimations with respect to subgroups of employees (women and men, blue and white collar workers). In the case of employees' wages we use OLS estimations. Accounting for the ordinal nature of the variable job satisfaction we use an ordered probit approach. The group of employees, who face a works council in 2006, acts as the treatment group. Employees without a works council in both years serve as the control group. The simplest equation for examining the impact of a works council's introduction is

$y=\alpha+\beta \cdot 2006+\gamma \cdot$ works council in $2006+\delta \cdot 2006^{*}$ works council in $2006+\lambda \cdot X^{\prime}+u$

where $y$ is the outcome variable of interest (wage respectively job satisfaction). The time dummy variable "2006” specifies the changes in wages (job satisfaction) over time. The variable "works council in 2006" captures possible differences between the treatment and the control group before the change in the works council's status takes place. The time dummy variable is interacted with the variable "works council in 2006”. The corresponding estimated coefficient $\hat{\delta}$ is the one of most interest. Let $\bar{y}_{\text {control group,2001 }}$ denote the average of $\mathrm{y}$ for the control group in the first year and $\bar{y}_{\text {control group } 2006}$ the average of $\mathrm{y}$ for the control group in the second year. Define $\bar{y}_{\text {treatmentgroup,2001 }}$ and $\bar{y}_{\text {treatmentgroup,2006 }}$ for the treatment group in the corresponding way. Then $\hat{\delta}$ can be expressed as the difference-in difference estimator (see Wooldridge, 2002):

$$
\hat{\delta}=\left(\bar{y}_{\text {treatment group ,2006 }}-\bar{y}_{\text {treatment group ,2001 }}\right)-\left(\bar{y}_{\text {contro 1 group ,2006 }}-\bar{y}_{\text {contro 1 group , 2001 }}\right) \text {. }
$$


The interaction term, therefore, indicates particular increases for the treatment group with respect to wages and job satisfaction.

\section{Results}

Presenting the results, we will start with the relation of the existence of a works council and employees' wages and then turn to job satisfaction.

\section{Works councils and wages}

As a first indicator, we examine the wage changes of employees between 2001 and 2006. As mentioned above, we distinguish two subgroups here with respect to the existence of a works council in 2001 and 2006. Next to the group of employees without a works council in both years we consider the group of employees who face a works council only in 2006. Focusing on these two groups, our sample is restricted to 1021 employees for which we have information for both years. The average real wage increase for these individuals is 0.05 in the five year period. It turns out that the average wage increase is higher for employees who face a works council in 2006. A bivariate difference is slightly significant between both groups (t-test for the independent sample, $\mathrm{p}=0.097$ ).

About half of individuals in the group of employees with a works council in 2006 change their job during the observation period. The corresponding fraction for the groups without a change in works councils status is only 0.23 . Therefore, we have a look at employees, who have not changed their firm during the observation period, in order to avoid a special impact of job turnover. Hereby, we receive a reduced sample of 739 employees, whereas 282 individuals switch to another firm. The average real wage increase does not differ between stayer and mover. Although, we find particular high wage increases for people who move to a firm with a works council during the observation period, there are no pairwise significant differences between subgroups (neither for stayer nor for mover). One explanation for the higher wage increases of mover compared to stayer may be that employees move to larger firms so that rather firm size differentials are examined. Indeed, 0.72 of employees with a 
works council only in 2006 move to a larger firm, whereas only 0.05 move to a smaller one.

These differences in wage changes cannot be interpreted as works council effects at all. It is well known from previous research that firms with works councils differ considerably from those without works councils; e.g. the probability of a works council increases with firm size (Schnabel and Wagner, 2001; Addison et al., 2003).

Table 2: Average wages and change in wages for subgroups from 2001 to 2006

\begin{tabular}{|c|c|c|c|c|c|c|c|}
\hline & & \multirow[b]{2}{*}{$\mathbf{N}$} & \multicolumn{2}{|c|}{2001} & \multicolumn{2}{|c|}{2006} & \multirow{2}{*}{$\begin{array}{c}\text { Increase } \\
\qquad \mathbf{w} \\
\end{array}$} \\
\hline & & & Mean & SD & Mean & SD & \\
\hline \multirow{3}{*}{$\begin{array}{l}\text { Whole } \\
\text { sample }\end{array}$} & All employees & 1021 & 2238.89 & 1220.98 & 2350.53 & 1358.76 & 0.050 \\
\hline & Works council in 2006 & 193 & 2303.19 & 1222.89 & 2512.41 & 1421.55 & 0.091 \\
\hline & No works council in both years & 828 & 2223.91 & 1219.60 & 2312.80 & 1341.79 & 0.040 \\
\hline \multirow{3}{*}{ Stayer } & All employees & 739 & 2268.92 & 1237.07 & 2382.87 & 1399.12 & 0.050 \\
\hline & Works council in 2006 & 98 & 2292.88 & 1077.34 & 2472.37 & 1393.13 & 0.078 \\
\hline & No works council in both years & 641 & 2265.26 & 1260.43 & 2369.19 & 1400.62 & 0.046 \\
\hline \multirow{3}{*}{ Mover } & All employees & 282 & 2160.21 & 1172.65 & 2265.78 & 1245.20 & 0.049 \\
\hline & Works council in 2006 & 95 & 2313.81 & 1362.58 & 2553.74 & 1456.52 & 0.104 \\
\hline & No works council in both years & 187 & 2082.17 & 1058.76 & 2119.49 & 1098.39 & 0.018 \\
\hline
\end{tabular}

In the following multivariate analysis, we examine whether these results also hold when controlling for a number of individual and job based characteristics. We therefore make use of the panel character of our data and provide some difference-indifferences estimations as described above. We have argued that the existence of a works council may not only have an effect on wages in general, but for women and blue collar workers in particular. Hence, we also run estimations for several subgroups of employees.

The results from model (1) of Table 3 indicate that wages of employees who face a works council in 2006 do not differ from those without a works council in both years. The interaction term is not significant, either. Therefore, a change in works council status does not increase wages. This result is in line with Kraft \& Lang 
(2008) who also examines the effect of a works council's introduction on wages. However, the authors neither distinguish between job mover and stayer nor control for the economic situations of the firms.

As hinted above, the overall sample contains both mover and stayer. The group "works council only in 2006" has to be interpreted differently with regard to these groups. A works council is introduced in certain firms when considering stayer. In contrast, mover are likely to switch to firms with existing works councils.

Due to these obvious selection effects, we also have a closer look at employees who do not change their firm during the observation period (model 2), and respectively at employees who move to another firm (model 3). The coefficient of the interaction term is not significant for stayer. Therefore, we cannot find evidence for a wage effect of the introduction of works councils. Employees, who face a works council in 2006, already received higher wages before this institution has been established. Considering mover only in model (3), we cannot find a wage effect for employees, who move into a firm with a works council, either.

The majority of control variables is also significantly associated with wages. The results are as expected and include an inverted u-shaped relationship for age, for instance. Years of schooling, actual working hours or tenure have positive effects on wages. Moreover, men, white collar workers and fulltime employees earn significantly more. We also find the well established firm size and industry differentials. Furthermore, employees with concerns about job security have significantly lower wages.

Finally, we run separate difference-in-differences estimations with respect to sex (women and men) and occupational status (blue and white collar workers) in order to look at the effect of a works council's introduction on wages for these subgroups. The results show that the coefficients of the interaction terms are not significant, though (see Table A in the appendix). Differences in wages between both subgroups in 2001 are driven by women and blue collar workers.

To sum up, we do not find support for our hypothesis of a positive link between the change in the works councils' status and employees' wages. Separating our analysis to subgroups of stayer and mover, we do not find significant effects, either. 
Table 3: Difference-in-differences estimations on wages

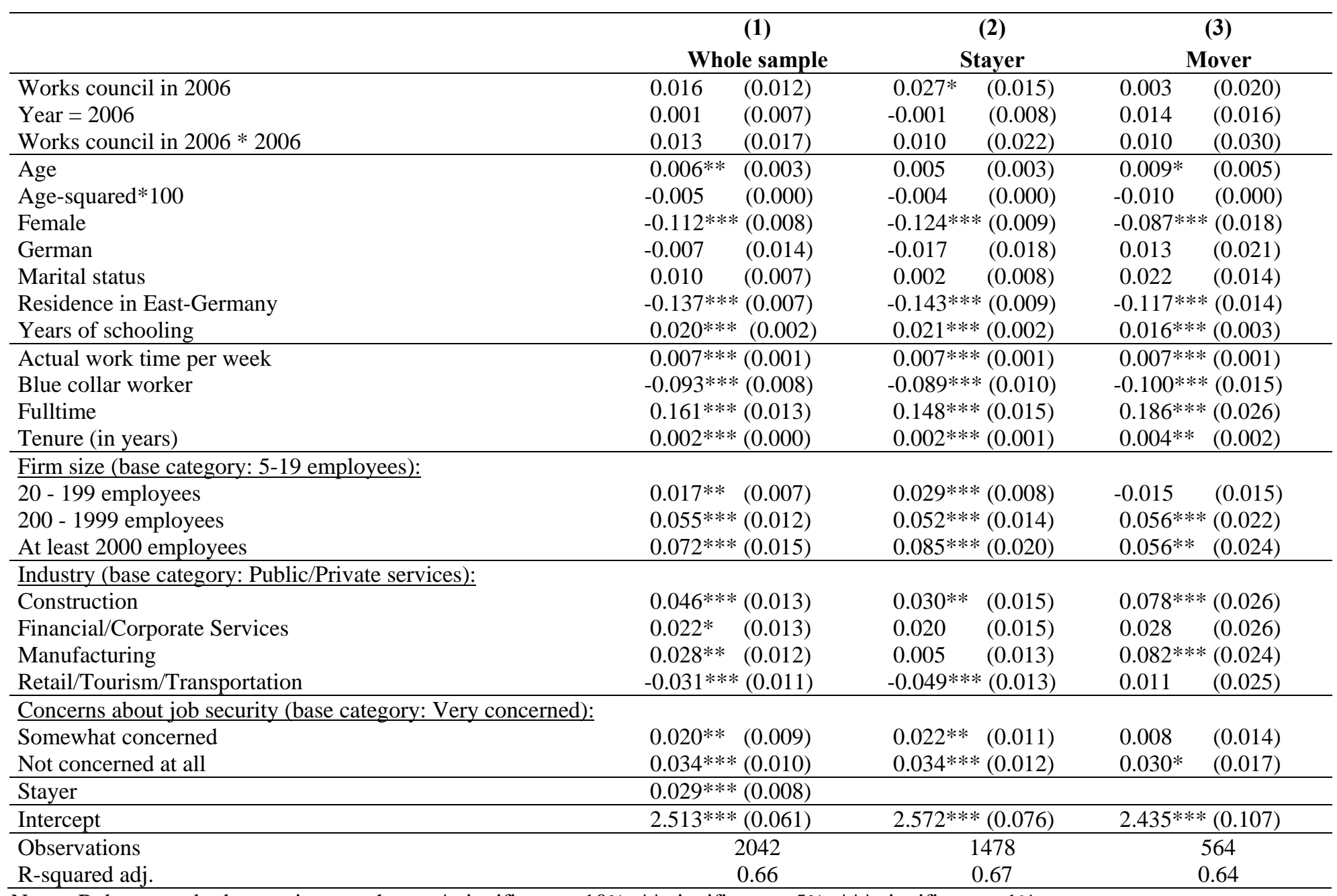

Notes: Robust standard errors in parentheses. * significant at 10\%; ** significant at 5\%; *** significant at $1 \%$ 


\section{Works councils and job satisfaction}

We now turn to results with regard to the relation of works councils and job satisfaction and choose a similar empirical approach. As a first step we focus on changes of job satisfaction - measured as the difference between its reported levels in 2006 and 2001 - for the two subgroups of individuals with two observations mentioned above (see Table 4). Job satisfaction decreases in the amount of 0.48 points on average. It turns out that the average job satisfaction decrease in absolute terms is lower for employees, who face a works council in 2006 but not in 2001. The difference to the group without a works council in each year is significant (t-test for the independent sample, $\mathrm{p}=0.003)$. Moreover, we have a look at employees, who have and have not changed their firm during the observation period. Job satisfaction of both subgroups of stayer decreases over the years. In contrast, mover benefit from job change in terms of job satisfaction. Employees with a works council in 2006 report somewhat lower decreases in job satisfaction, when staying at their firm, and higher increases in job satisfaction, when moving to a new firm. The differences are not statistically significant, though. Therefore, differences across both groups are supposed to be driven by mover to firms with a works council. This group of employees was relatively dissatisfied with respect to jobs in 2001 (6.38 compared to 7.30 for the other 926 observations).

Table 4: Average job satisfaction and change in job satisfaction for subgroups from 2001 to 2006

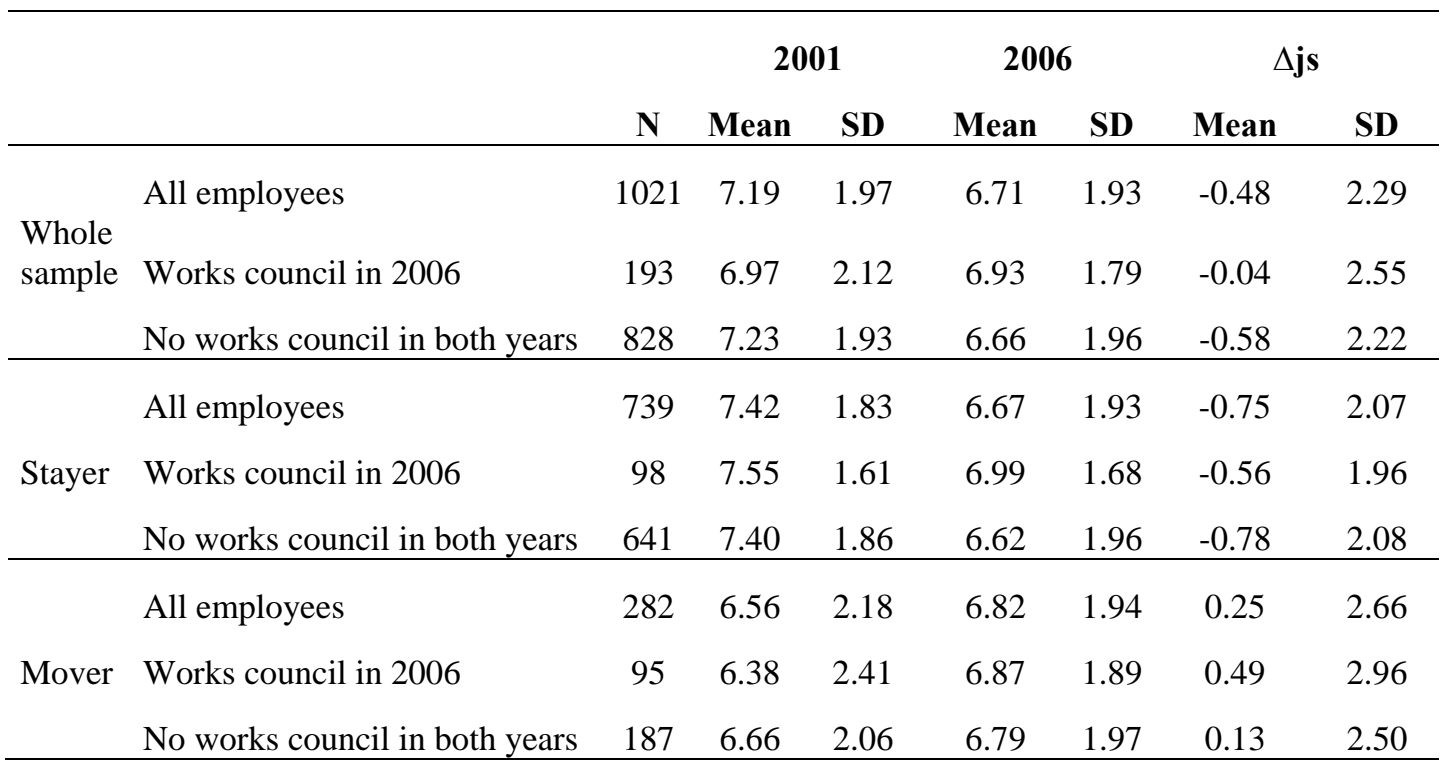


We again examine, whether these results also hold when controlling for a number of individual and job based characteristics in the following multivariate analyses. Table 5 provides some more difference-in-differences estimates.

Taking both groups of mover and stayer into account, the job satisfaction of the year 2001 of employees who face a works council in 2006 do not differ from that of employees without a works council in both years. However, the interaction term is significantly positive indicating that the change of works council status increases job satisfaction (model 1). This result does not hold if we exclude mover from our estimation. In model 2 the subgroups do not differ significantly in job satisfaction and the interaction term is not significant, either. Therefore, the introduction of a works council does not lead to a higher job satisfaction. In both models the time dummy shows that job satisfaction decreases over time. Considering mover only in model (3), the interaction term of a works council in 2006 and the time dummy is significantly positive. Therefore, moving into a firm with works council has a positive effect on job satisfaction of employees. It can be argued that their low job satisfaction in the old firm is the reason for their job change.

With respect to the other independent variables employees' job satisfaction increases with a better health status and less concerns about job security. However, the coefficients of some other independent variables differ between stayer and mover. For example, results for stayer (2) include that job satisfaction increases in wages. Besides we find a negative effect for schooling, which may be interpreted as differences in aspiration levels. Indeed, the bivariate correlation between schooling and job satisfaction is positive.

Finally, we examine whether certain subgroups of employees benefit from the introduction of a works council with respect to job satisfaction. Again we run separate difference-in-differences estimations for sex (women and men) and the occupational status (blue and white collar workers). The results show that a change in the works council's status increases job satisfaction of women in particular. Job satisfaction of both blue collar and white collar workers is affected (see Table B in the appendix). If we distinguish between stayer and mover, only the interaction term for blue collar mover remains significant. 


\section{Table 5: Difference-in-differences estimations on job satisfaction}

\begin{tabular}{|c|c|c|c|c|}
\hline \multirow{2}{*}{ Works council in 2006} & $\begin{array}{c}\text { (1) } \\
\text { Whole sample }\end{array}$ & $\begin{array}{c}(2) \\
\text { Stayer }\end{array}$ & \multicolumn{2}{|r|}{$\begin{array}{c}\text { (3) } \\
\text { Mover }\end{array}$} \\
\hline & $(0.090)$ & $(0.113)$ & -0.217 & $(0.150)$ \\
\hline Year $=2006$ & $-0.209 * * *(0.054)$ & $-0.312 * * *(0.065)$ & 0.122 & $(0.120)$ \\
\hline Works council in $2006 * 2006$ & $0.342 * * *(0.117)$ & $0.158 \quad(0.147)$ & $0.321^{*}$ & $(0.199)$ \\
\hline Age & $(0.020)$ & $(0.026)$ & -0.011 & $(0.035)$ \\
\hline Age-squared $* 100$ & $(0.000)$ & $(0.000)$ & 0.008 & $(0.000)$ \\
\hline Female & $(0.065)$ & $(0.077)$ & $-0.212 *$ & $(0.125)$ \\
\hline German & $(0.105)$ & $(0.135)$ & -0.036 & $(0.183)$ \\
\hline \multicolumn{5}{|c|}{ Health status (base category: Bad): } \\
\hline Not so good & $(0.321)$ & $(0.364)$ & 0.535 & $(0.722)$ \\
\hline Satisfactory & $(0.313)$ & $(0.353)$ & 0.823 & $(0.703)$ \\
\hline Good & $0.853 * * *(0.313)$ & $0.745^{* *}(0.353)$ & $1.218^{*}$ & $(0.703)$ \\
\hline Very good & $1.217 * * *(0.324)$ & $1.149^{* * *}(0.368)$ & $1.542^{* *}$ & $(0.716)$ \\
\hline Marital status & $0.164 * * *(0.056)$ & $0.180^{* * *}(0.066)$ & 0.162 & $(0.102)$ \\
\hline Residence in East-Germany & $(0.058)$ & $(0.071)$ & 0.149 & $(0.106)$ \\
\hline Years of schooling & $-0.031 * * \quad(0.013)$ & $-0.044^{* * *}(0.015)$ & 0.010 & $(0.024)$ \\
\hline Actual work time per week & $(0.003)$ & $(0.004)$ & 0.002 & $(0.006)$ \\
\hline Blue collar worker & $-0.169 * * *(0.059)$ & $-0.195 * * *(0.070)$ & -0.098 & $(0.110)$ \\
\hline Fulltime & $-0.029 \quad(0.095)$ & $-0.008 \quad(0.111)$ & -0.175 & $(0.192)$ \\
\hline Monthly gross wage $* 100$ & $0.005 * \quad(0.000)$ & $0.009 * * *(0.000)$ & -0.005 & $(0.000)$ \\
\hline Tenure (in years) & $-0.012 * * *(0.004)$ & $-0.011^{* *}(0.004)$ & -0.000 & $(0.014)$ \\
\hline \multicolumn{5}{|c|}{ Firm size (base category: 5-19 employees): } \\
\hline 20 - 199 employees & $(0.051)$ & $-0.110^{*} \quad(0.061)$ & -0.017 & $(0.104)$ \\
\hline 200 - 1999 employees & $(0.085)$ & $-0.175^{*} \quad(0.102)$ & -0.072 & $(0.152)$ \\
\hline At least 2000 employees & $(0.110)$ & -0.118 & -0.011 & (0.187) \\
\hline \multicolumn{5}{|c|}{ Industry (base category: Public/Private services): } \\
\hline Construction & $(0.102)$ & $(0.122)$ & 0.033 & $(0.200)$ \\
\hline Financial/Corporate Services & $(0.096)$ & $(0.113)$ & -0.142 & $(0.182)$ \\
\hline Manufacturing & $(0.089)$ & $(0.103)$ & -0.057 & $(0.175)$ \\
\hline Retail/Tourism/Transportation & $(0.087)$ & $(0.104)$ & -0.166 & $(0.170)$ \\
\hline \multicolumn{5}{|c|}{ Concerns about job security (base category: Very concerned): } \\
\hline Somewhat concerned & $0.452 * * *(0.069)$ & $0.503 * * *(0.084)$ & $0.360^{* * *}$ & $*(0.118)$ \\
\hline Not concerned at all & $0.865 * * *(0.077)$ & $0.914 * * *(0.093)$ & $0.817^{* * *}$ & $*(0.143)$ \\
\hline Stayer & $0.176 * * *(0.060)$ & & & \\
\hline Observations & 2042 & 1478 & & 564 \\
\hline McFadden R-squared & 0.06 & 0.07 & & 0.04 \\
\hline
\end{tabular}

Notes: Robust standard errors in parentheses. * significant at $10 \%$;* significant at $5 \%$; *** significant at $1 \%$. 
Stayer do not benefit significantly. Sample sizes are considerably reduced, though. Therefore, the positive effect of a works council in model 3 is driven by blue collars mover.

To sum up, a change in the works council's status is positively associated with employees' job satisfaction. However, this effect is driven by mover. Moving to $a$ new firm with a works council leads to higher reported level of job satisfaction. The introduction of a works council in the workplace does not lead to a higher job satisfaction, indicating the relevance of selection effects due to job change.

\section{Discussion}

Aiming to discuss the results in more detail, it is necessary to have a closer look on the institutional environment of the German industrial relation system concerning works councils. Codetermination rights of German works councils are laid down in the Works Constitution Act (WCA). The WCA was introduced in 1952 and extended in 1972, 1989 and 2001. According to this law, works councils can be set up in all establishments with five or more permanent employees. They are mandatory, but have to be initiated by the employees so that they are not present in all appropriate establishments. The actual presence of works councils depends on characteristics such as firm size, firm age and the gender composition of the workforce (Addison et al., 2003). In contrast to German unions that bargain at the industry level, works councils act at the establishment level. However, there are close connections between these two institutions. In practice the vast majority of works councilors are union members, although the share has declined over the years (Addison et al., 2007; Goerke and Pannenberg, 2007).

In our empirical analysis we will focus on the years 2001 and 2006, which are the only two years with information on works council's existence in the GSOEP. In July 2001 the most recent reform of the WCA has been enacted. It aims to stimulate works council formation, to strengthen the existing works councils and to improve the efficiency of the works council tools. Also the rights of works councils concerning employment protection, further training and procedures of team working arrangements have been extended (Addison et al. 2004). 
Some studies argue that works councils increase wages (e.g. Hübler and Jirjahn, 2003, Addison et al. (2010)). Our examination does not confirm this interrelation. Previous studies use other data sets and/or cross section analyses. Another reason for lacking evidence in this contribution might be that firms, which introduced a works council between 2001 and 2006, already paid higher wages before the introduction occured, so that there is less scope for a further increase. This consideration is in line with our result for stayer. Then, establishing a works council can be rather interpreted as a hint for a workforce's motivation to protect their rents. However, it is not the objective of this study to distinguish between effects concerning the allocation and distribution of rents (see instead Jirjahn, 2009; Beckmann et al., 2010) and we do not examine the effect of works councils on firms' productivity (e.g. Hübler and Jirjahn, 2003; Wagner et al, 2006). Another argument of lacking evidence of works councils' effects on wages is that we do not know exactly the timing of the works councils' introduction If the introduction has been taken place shortly before 2006, there may not be sufficient time for a works council to have an influence on employees’ wages.

The same argument may also hold for job satisfaction. However, the effect of implementing a works council may only be transitory and has already been disappeared in 2006. If works councils cannot fulfill employees' expectations or aspirations after an introduction, their job satisfaction will decrease again. This is in line with results from Powdthavee (2010) who examines unions' effects on job satisfaction for the UK. Indeed, workers report, on average, a significant net increase in overall job satisfaction directly after unionization. But shortly after this event, workers' job satisfaction returns to the former level.

We argued above that works councils represent the interests of blue collar workers in particular. We do not find support for this consideration. Some arguments can be given that are based on the institutional characteristics of the German case. First, the amended WCA also strengthens the works councils' influence in matters of employees' training (Addison et al. 2004). Bellmann and Ellguth (2006) show that firms with works councils have a higher training coverage of the workforce. Georgellis and Lange (2007) find particular relevance of training for white collar workers and a positive relationship of employer financed training with job satisfaction. Second, with the recent reform of the WCA the promotion of work- 
family-reconciliation by a works council is explicitly fixed by law. Some studies point out that work-life balance provisions have become more and more important due to changes in family structure and employees' priorities (Brandon and Temple, 2006; Giardini and Kabst, 2008). If such activities are realized in firms, works councils mostly initiate them (Botsch et al., 2006). Also Heywood and Jirjahn (2009) state that family friendly working practices are more likely in firms with works councils. Relevance of part-time work may act as an indicator of the importance of work-life balance. Part-time work is much more and increasingly relevant for white collar workers. Our data show that the share of part-time employees among white collar workers increases from 0.229 in 2001 to 0.242 in 2006 and is more than twice as high as the constant fraction among blue collar workers. Indeed, the results show that not only blue collar workers but also white collars benefit from a change in the works council's status.

\section{Conclusion}

In this paper we examine the possible impact of a change in works council's status on wages and job satisfaction for employees in Germany. Since works councils may affect certain groups of employees in particular, we also analyse subgroups with respect to sex and the occupational status. We focus on the comparison of employees, who do not face a works council over the whole observation period, and those, who do report a change in works council coverage from "no" to "yes". For the first time, we distinguish between mover to firms with works councils and introduction of works councils in firms of employees, who stay at a firm during the observation period.

We do not find a significant effect of changes in works council status on wages. However, difference-in-difference estimates indicate a positive effect on job satisfaction. This result is more pronounced for women than for men. The effect is rather driven by employees, who move to another firm during the observation period. We cannot find particular effects of an introduction of a works council for individuals, who stay at their firm. We do not find find particular effects for blue collar workers compared to white collar employees, either. 
As mentioned above, we are not able to examine transitory effects that have already been disappeared or long-term effects that are not yet present due to lack of data. The quality of further research depends on the quality of available data. It would be very useful to implement the question about works councils in the regular yearly questionnaire of the GSOEP or other surveys among individuals. It would then be possible to examine the short and long-term effects of the existence and introduction of works councils in some more detail. As our contribution shows, further research with longitudinal data is also supposed to distinguish between mover and stayer, because of considerable differences of interpreting the results. 


\section{References}

Addison, J. T., Schnabel, C. and Wagner, J. (1996) German Works Councils, Profits, and Innovation, Kyklos 49, 555-582.

Addison, J. T., Siebert W. S., Wagner, J. and Wei, X. (2000) Worker Participation and Firm Performance: Evidence from Germany and Britain, British Journal of Industrial Relations 38, 7-48.

Addison, J. T., Schnabel, C. and Wagner, J. (2001) Works councils in Germany: their effects on establishment performance, Oxford Economic Papers 53, 659-694.

Addison, J. T., Bellmann, L., Schnabel, C. and Wagner, J. (2003) German works councils old and new: incidents, coverage and determinants, Schmollers Jahrbuch 123, 339-358.

Addison, J. T., Bellmann, L., Schnabel, C. and Wagner, J. (2004) The reform of the German Works Constitution Act: a critical assessment, Industrial Relations 43, 392420.

Addison, J. T., Schnabel, C. and Wagner, J. (2007) The (parlous) state of German unions, Journal of Labor Research 28, 3-18.

Addison, J. T., Teixeira, P. and Zwick, T. (2010) German works councils and the anatomy of wages, Industrial and Labor Relations Review 63, 247-270.

Artz, B. (2010) The Impact of Union Experience on Job Satisfaction, Industrial Relations 49, 387-405.

Askildsen, J. E., Jirjahn, U. and Smith, S. C. (2006) Works councils and environmental investment: Theory and evidence from German panel data, Journal of Economic Behavior \& Organization 60, 346-372.

Bayard K., Hellerstein J., Neumark D. and Troske K. (2003) New Evidence on Sex Segregation and Sex Differences in Wages from Matched Employee-Employer Data, Journal of Labor Economics 21, 887-922.

Beckmann, M., Föhr, S., Kräkel, M. (2010) Rent seeking, employment security, and works councils: theory and evidence for Germany, Schmalenbach Business Review 62, 2-40.

Bellmann, L. and Ellguth, P. (2006) Verbreitung von Betriebsräten und ihr Einfluss auf die betriebliche Weiterbildung, Jahrbücher für Nationalökonomie und Statistik 226, 487-504.

Bender, K. A. and Sloane P. J. (1998) Job Satisfaction, Trade Unions, and ExitVoice. Revisited, Industrial and Labor Relations Review 51, 222-240.

Borjas, G. J. (1979) Job satisfaction, wages, and unions, The Journal of Human Resources 14, 21-40. 
Botsch, E., Lindecke, C. and Wagner, A. (2006): Familienfreundlicher Betrieb - ein Blick in die Praxis, WSI-Mitteilungen 59, 485-491.

Brandon, P. D. and Temple, J. B. (2006) Family provisions at the workplace and their relationship to absenteeism, rentention, and productivity of workers: timely evidence from prior data, Australian Journal of Social Issues 42, 447-460.

Flabbi, L. (2010) Gender discrimination estimation in a search model with matching and bargaining, International Economic Review 51, 745-783.

Frege C. M. (2002) A Critical Assessment of the Theoretical and Empirical Research on German Works Councils, British Journal of Industrial Relations 40, 221-248.

Freeman, R. B. (1978) Job Satisfaction as an Economic Variable, American Economic Review 68, 135-141.

Freeman, R. B. and Medoff, J. (1984) What Do Unions Do?, Basic Books, New York.

Freeman, R. B. and Lazear, E. P. (1995) An economic analysis of works councils, in Works Councils - Consultation, Representation and Cooperation in Industrial Relations, (Eds) J. Rogers and W. Streeck, University of Chicago Press, Chicago, pp. 27-50.

Freeman, R. B. and Rogers, J. (1999) What Workers Want, ILR Press, Ithaca.

Frey, B., Benz, M. and Stutzer, A. (2004) Introducing procedural utility: not only what, but also how matters, Journal of Institutional and Theoretical Economics 160, 377-401.

Gardeazabal, J. and Ugidos, A. (2005) Gender wage discrimination at quantiles, Journal of Population Economics 18, 165-179.

Gartner, H. and Stephan, G. (2004) How collective contracts and works councils reduce the gender wage gap, IAB Discussion Paper No 200407.

Georgellis, Y. and Lange, T. (2007) Participation in continuous, on-the-job training and the impact on job satisfaction: longitudinal evidence from the German labour market, The International Journal of Human Resource Management 18, 969-985.

Giardini, A. and Kabst, R. (2008) Effects of work-family human resource practices: a longitudinal perspective, The International Journal of Human Resource Management 19, 2079-2094.

Goerke, L. and Pannenberg, M. (2007) Trade union membership and works councils in West Germany, Industrielle Beziehungen 14, 154-175.

Hammer T. H. and Avgar A. (2005) The impact of unions on job satisfaction, organizational commitment and turnover, Journal of Labor Research 26, 241-266. 
Heinze, A. and Wolf, E. (2010) The intra-firm gender wage gap: a new view on wage differentials based on linked employer-employee data, Journal of Population Economics 23, 851-879.

Heywood, J. S., Hübler, O. and Jirjahn, U. (1998) Variable Payment Schemes and Industrial Relations: Evidence from Germany, Kyklos 51, 237-257.

Heywood, J. S. and Jirjahn, U. (2002) Payment schemes and gender in Germany, Industrial and Labor Relations Review 56, 44-64.

Heywood, J. S. and Jirjahn, U. (2009) Family-friendly practices and worker representation in Germany, Industrial Relations 48, 121-145.

Hirschman, A. (1970) Exit, Voice and Loyality. Responses to Decline in Firms, Organizations and States, Harvard University Press, Cambridge.

Hübler, O. and Jirjahn U. (2003) Works councils and collective bargaining in Germany: the impact on productivity and wages, Scottish Journal of Political Economy 50, 471-491.

Jirjahn, U. (2009) The introduction of works councils in German establishments rent seeking or rent protection?, British Journal of Industrial Relations 47, 521-545.

Jirjahn, U. (2010) Works councils and employment growth in German establishments, Cambridge Journal of Economics 34, 475-500.

Jirjahn, U. and Tsertsvadze, G. (2006) Betriebsräte und Arbeitszufriedenheit, Jahrbücher für Nationalökonomie und Statistik 226, 537-561.

Jirjahn, U. and Kraft, K. (2007) Intra-firm wage dispersion and firm performance - is there a union relationship?, Kyklos 60, 231-253.

Kraft, K. and Lang, J. (2008) The causes and consequences of adopting a works council, Jahrbücher für Nationalökonomie und Statistik 228, 512-532.

Laffont, J. J. and Tirole, J. (1988) The dynamics of incentive contracts, Econometrica 56, 1153-1175.

Light, A. and Ureta, M. (1990) Gender differences in wages and job turnover among continuously employed workers, American Economic Review 80, 293-297.

Mincer, J. (1974) in Schooling, experience, and earnings, Columbia University Press, New York.

Nergaard, K., Dølvik, J. E., Marginson, P., Díaz, J. A. and Bechter, B. (2009) Engaging with Variable Pay: A Comparative Study of the Metal Industry, European Journal of Industrial Relations 15, 125-146.

Phipps, S., Burton, P., Lethbridge, L. (2001) In and out of the labour market:longterm income consequences of child-related interruptions to women's paid work, Canadian Journal of Economics 34, 411-429. 
Powdthavee, N. (2010) Anticipation, free-rider problem, and adaptation to trade union: re-examining the curious case of dissatisfied union members, Industrial and Labor Relations Review, forthcoming.

Schnabel, C. and Wagner, J. (2001) Verbreitung und Bestimmungsgründe verschiedener Formen der Arbeitnehmerpartizipation in Industriebetrieben, Industrielle Beziehungen 8, 445-462.

Wagner, J., Schank, T., Schnabel, C. and Addison, J. T. (2006) Works councils, labor productivity and plant heterogeneity: first evidence from quantile regressions, Jahrbücher für Nationalökonomie und Statistik 226, 505-518.

Wooldridge, J. (2002) Econometric analysis of cross section and panel data, MIT Press, Cambridge.

Zwick, T. (2004) Employee participation and productivity, Labour Economics 11, 715-740. 


\section{Appendix}

Table A: Difference-in-differences regressions on wages with respect to certain subgroups

\begin{tabular}{|c|c|c|c|c|}
\hline & & $\begin{array}{c}\text { (1) } \\
\text { Whole sample }\end{array}$ & $\begin{array}{c}(2) \\
\text { Stayer }\end{array}$ & $\begin{array}{l}(3) \\
\text { Mover }\end{array}$ \\
\hline \multirow{4}{*}{ Women } & Works council in 2006 & $0.021 \quad(0.020)$ & $0.042 * \quad(0.026)$ & $-0.004(0.033)$ \\
\hline & Year $=2006$ & $0.006 \quad(0.012)$ & $(0.014)$ & $0.022(0.027)$ \\
\hline & Works council in $2006 * 2006$ & $0.002(0.028)$ & $(0.038)$ & $0.002(0.046)$ \\
\hline & $\mathrm{N}$ & 860 & 642 & 218 \\
\hline \multirow{4}{*}{ Men } & Works council in 2006 & $0.078 \quad(0.015)$ & $(0.018)$ & $0.009(0.026)$ \\
\hline & Year $=2006$ & $-0.005(0.008)$ & $-0.005 \quad(0.010)$ & $0.007(0.020)$ \\
\hline & Works council in $2006 * 2006$ & $0.022(0.021)$ & $(0.025)$ & $0.023(0.039)$ \\
\hline & $\mathrm{N}$ & 1182 & 836 & 346 \\
\hline \multirow{4}{*}{ Blue collar workers } & Works council in 2006 & $0.023 *(0.013)$ & $0.044 * * *(0.014)$ & $-0.004(0.025)$ \\
\hline & Year $=2006$ & $-0.009(0.010)$ & $-0.007 \quad(0.012)$ & $0.001(0.019)$ \\
\hline & Works council in $2006 * 2006$ & $0.006 \quad(0.020)$ & $-0.006 \quad(0.025)$ & $0.007(0.036)$ \\
\hline & $\mathrm{N}$ & 825 & 579 & 246 \\
\hline \multirow{4}{*}{ White collar workers } & Works council in 2006 & $0.011 \quad(0.019)$ & $(0.026)$ & $0.007(0.031)$ \\
\hline & Year $=2006$ & $0.007 \quad(0.010)$ & $(0.011)$ & $0.021(0.025)$ \\
\hline & Works council in $2006 * 2006$ & $0.018 \quad(0.025)$ & $(0.034)$ & $0.017(0.043)$ \\
\hline & $\mathrm{N}$ & 1217 & 899 & 318 \\
\hline
\end{tabular}

Notes: Robust standard errors in parentheses. ${ }^{*}$ significant at $10 \% ;{ }^{* *}$ significant at $5 \% ;{ }^{* * *}$ significant at $1 \%$.

Other independent variables included. 
Table B: Difference-in-differences regressions on job satisfaction with respect to certain subgroups

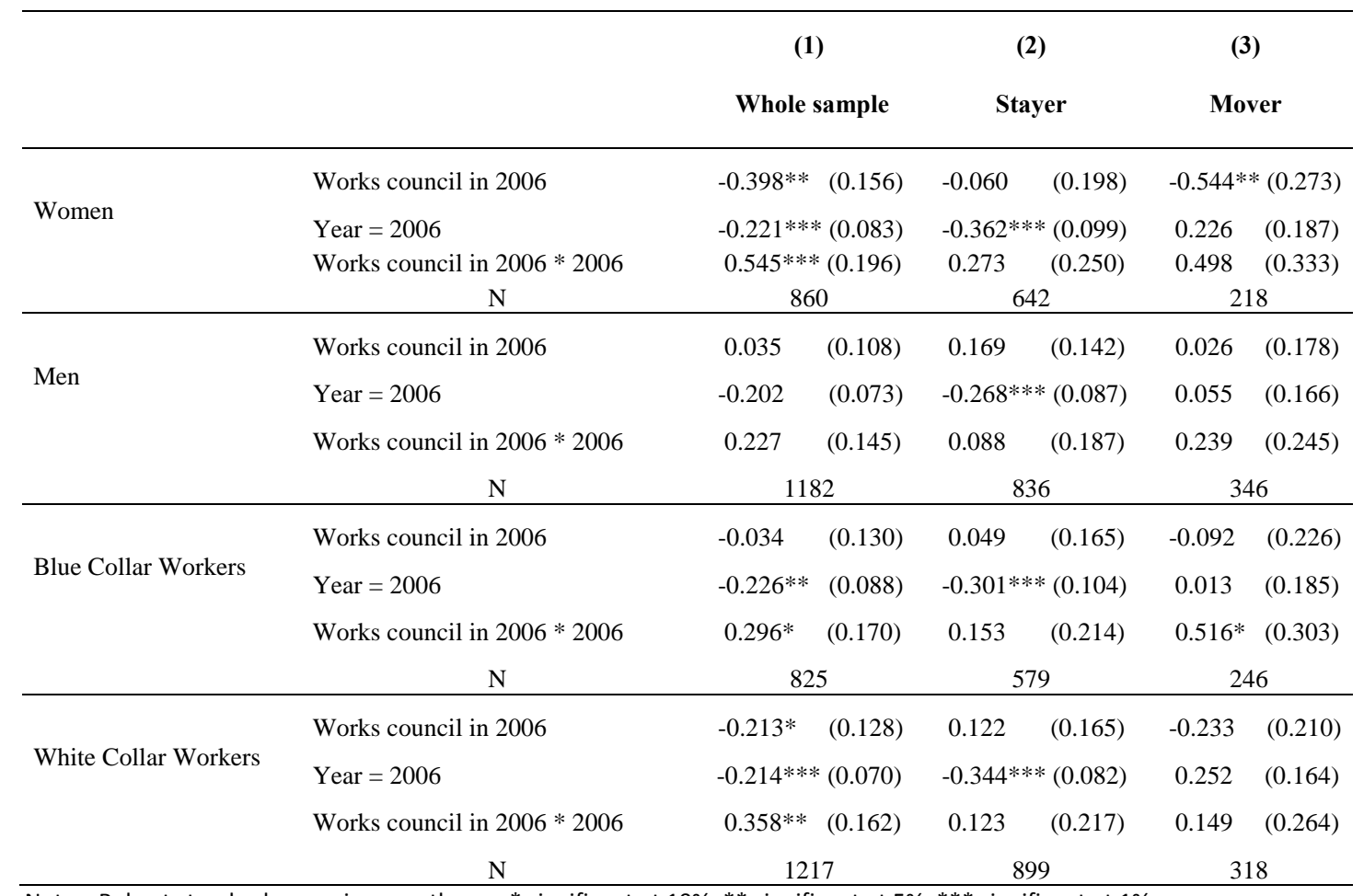

Notes: Robust standard errors in parentheses. ${ }^{*}$ significant at $10 \% ;{ }^{* *}$ significant at $5 \% ; * * *$ significant at $1 \%$. Other independent variables included. 